\title{
Kritik terhadap Teologi Proses dan Pembelaan terhadap Pandangan “Greater Good” dalam Menanggapi Masalah Kejahatan
}

\author{
Jessica Novia Layantara* \\ *Penulis adalah dosen di Universitas Pelita Harapan dalam Fakultas Liberal Arts \\ Email: jessica.layantara@uph.edu
}

\begin{abstract}
Abstrak: Selama berabad-abad, para teolog Kristen mencoba menanggapi pergumulan filosofis mengenai masalah kejahatan. Bapa-bapa Gereja dan tokoh-tokoh reformasi di masa lalu telah mencoba menanggapi permasalahan ini dengan argumen kebaikan yang lebih tinggi (greater good). Tetapi solusi-solusi semacam itu ditolak mentah-mentah setelah peristiwa Holocaust (Auschwitz), yang merupakan peristiwa kejahatan sangat dahsyat dan mengakibatkan penderitaan banyak sekali orang. Solusi tradisional dianggap sudah tidak relevan dalam menanggapi masalah kejahatan. Teologi proses kemudian mencoba menanggapi masalah ini dengan cara mereduksi atribut-atribut Allah. Tujuan karya tulis ini adalah untuk mengkritik pandangan kontemporer khususnya teologi proses dalam menanggapi masalah kejahatan, dan juga membela pandangan greater good sebagai solusi yang masih tetap dapat dipertahankan walaupun dengan beberapa penyesuaian.
\end{abstract}

Kata-kata kunci: Teodisi, Soft-determinism, Kompatibilisme, Kedaulatan Allah, Masalah Kejahatan, Holocaust, Auschwitz, Teologi Proses, Pembelaan Kehendak Bebas, Teodisi Pembentukan Jiwa, Greater Good Theodicy, John Calvin, John Feinberg

Abstract: Throughout the ages Christian theologians have attempted to understand, from a philosophical vantagepoint, the problem of evil. The Church Fathers as well as theologians during the era of the Reformation have offered a solution that argues from the basis of the greater good. However, solutions of that nature seem to ring hollow when one considers the magnitude and scope of the Holocaust (Auschwitz). In light of that historical reality traditional solutions to the problem of evil seem inadequate. Process theology attempts to overcome the impasse by restricting the attributes of God. The purpose of this article is to critically evaluate contemporary solutions to the problem of evil, especially process theology, as inadequate solutions. Further, to argue for the traditional positional argument of the greater good as offering a tenable solution.

Keywords: Theodicy, Soft-determinism, Compatibilism, Sovereignty of God, Problem of Evil, Holocaust, Auschwitz, Process Theology, Free Will Defense, Soul-shaping Theodicy, Greater Good Theodicy, John Calvin, John Feinberg 


\section{Pendahuluan}

Sejak zaman Bapa-bapa Gereja, masalah kejahatan merupakan masalah yang sangat penting dibahas. Teologi klasik menggambarkan sosok Allah sebagai sosok yang mahabaik dan mahakuasa. Kritik yang tidak dapat dihindari adalah, jika Tuhan benar-benar mahabaik dan mahakuasa, maka seharusnya tidak ada kejahatan. Kenyataannya, kejahatan terus terjadi dari zaman ke zaman, dan bahkan makin hebat. Ini memunculkan sebuah masalah filosofis: Jika Allah mahabaik dan mahakuasa, mengapa masih ada kejahatan? Seperti ungkapan Epicurus bahwa Allah:

... either wishes to take away evils, and is unable, or He is able, and is unwilling; or He is neither willing nor able, or He is both willing and able. If He is willing and is unable, He is feeble, which is not in accordance with the 2 character of God; If He is able and unwilling, He is envious, which is equally at variance with God; If He is neither willing nor able, He is both envious and feeble, and therefore not God; If He is both willing and able, which alone is suitable to God, from what source then are evils? Or why does He not remove, then? ${ }^{1}$

Pertanyaan-pertanyaan filosofis dan teologis seperti ini terus berusaha dijawab oleh para teolog dan filsuf Kristen. Kekristenan memercayai Allah yang bersifat personal, yang membuat Allah pasti memiliki sifat-sifat, termasuk mahabaik dan mahakuasa. Oleh sebab itu, masalah kejahatan menjadi masalah krusial yang harus ditanggapi oleh para teolog dan filsuf Kristen. Argumen-argumen yang men-

${ }^{1}$ Lactantius, "A Treatise on the Anger of God," dalam The Ante-Nicene Fathers, eds. Alexander Roberts \& James Donaldson, terj. William Fletcher, vol III (Grand Rapids: Eerdmans, 1951), 271, dikutip dalam Daniel B. Clendenin, "God is Great, God is Good: Question About Evil," Ashland Theological Journal 24 (1992): 1. coba untuk menanggapi masalah kejahatan ini disebut teodisi. ${ }^{2}$

Berbagai teodisi telah dimunculkan, dari zaman Bapa-bapa Gereja sampai zaman modern. Pada zaman Bapa-bapa Gereja, seorang teolog yang sangat berpengaruh dalam mengajukan teodisi adalah Agustinus. ${ }^{3}$ Pandangan Agustinus yang sangat umum adalah definisinya terhadap kejahatan sebagai "privatio boni” yang berarti kurangnya kebaikan (lesser good) dari yang seharusnya, yaitu yang Allah anugerahkan dalam setiap ciptaan. Agustinus berkata: "Evils, therefore, have their source in the good, and unless they are parasitic on something good, they are not anything at all." 4

Pandangan Agustinus ini diteruskan oleh para teolog reformasi, seperti Martin Luther dan John Calvin. Mereka menyetujui bahwa Allah tidak pernah menciptakan kejahatan karena natur Allah adalah baik. Kejahatan datang oleh karena dosa manusia, namun tidak di luar kedaulatan Allah. Kejahatan yang terjadi juga ada di dalam kehendak Allah, bukan karena Allah menyetujui kejahatan, melainkan karena Allah memiliki tujuan yang lebih baik (greater good) di balik setiap peristiwa kejahatan. Calvin berkata, "Allah telah mengetahui bahwa Adam akan jatuh di dalam dosa. Allah memang bisa mencegah terjadinya kejatuhan itu, namun Ia tidak menghendaki hal itu. Mengapa? Sangat tidak memungkinkan untuk kita memberikan satu alasan khusus terhadap apa yang dikehendaki Allah, kecuali karena Allah sedang mengarahkan kehendak-Nya pada rencana-Nya

\footnotetext{
${ }^{2}$ Kata "teodisi" pertama kali dimunculkan oleh G. W. Leibniz. Kata "teodisi" diambil dari bahasa Yunani theos [Tuhan] dan dike [keadilan]. John Hick mendefinisikan teodisi sebagai: "the defence of the justice and righteousness of God in face of the fact of evil." Lih. John Hick, Evil and the God of Love (Cleveland: Collins World, 1968), 6.
}

${ }^{3}$ Eugene Te Selle mengatakan bahwa masalah kejahatan (problem of evil) memiliki tempat yang sangat penting dalam seluruh pemikiran Agustinus. Lih. Eugene TeSelle, Augustine (Nashville: Abingdon, 2006), 21.

${ }^{4}$ Agustinus, Enchiridion IV.13-14, dikutip dalam Hick, Evil and the God, 54. 
lain." ${ }^{5}$ Pandangan greater good ini tetap menjadi sebuah acuan yang dikembangkan dari zaman ke zaman oleh para teolog. Pengembangan terhadap pandangan greater good ini melahirkan beberapa variasi tanggapan terhadap problem kejahatan, khususnya kejahatan moral, ${ }^{6}$ seperti teodisi/pembelaan kehendak bebas dan teodisi pembentukan jiwa. ${ }^{7}$

Namun demikian, masalah tidak selesai sampai di situ saja. Sebagian orang, khususnya kaum ateis, berpendapat bahwa teodisiteodisi yang berpusat kepada alasan greater good belum dapat menyelesaikan masalah kejahatan. Peristiwa yang diangkat untuk menyangkal pandangan ini adalah peristiwa Holocaust (Auschwitz). Bagaimana mungkin kejahatan yang mengakibatkan kematian lebih dari enam juta jiwa yang tidak bersalah akan menghasilkan kebaikan yang lebih tinggi? Paling tidak, jika memang Ia mengizinkan kejahatan terjadi, seharusnya kejahatan itu menjadi sebuah kejahatan yang terbatas, tidak sekejam dan semasif Holocaust. Oleh sebab itu alasan "kejahatan yang tidak bermakna" ini digunakan untuk melawan alasan greater good. Jane Mary Trau berkata,

... penderitaan yang tidak berguna atau yang tidak sewajarnya tampaknya sangat sulit dipercaya. Seorang ateis bahkan menyejajarkan eksistensi penderitaan dan eksistensi Allah. Bagi ateis tampaknya jelas bahwa jika Allah ada, maka tentunya kasus-kasus seperti penderitaan

${ }^{5}$ John Calvin, The Secret Providence, diedit oleh Paul Helm (Wheaton: Crossway, 2010), 76.

${ }^{6}$ Penulisan artikel ini akan lebih berfokus kepada penyelesaian kejahatan secara moral, meskipun dalam kesadaran penuh, penulis menyadari bahwa ada pula jenis kejahatan natural/alamiah.

${ }^{7}$ Teodisi kehendak bebas atau pembelaan kehendak bebas meyakini bahwa masalah kejahatan terjadi karena kehendak bebas manusia. Allah tidak menghentikannya karena tidak ingin mengintervensi kehendak bebas manusia. Namun, pada akhir zaman Tuhan akan mengalahkan kejahatan. Teodisi pembentukan jiwa meyakini bahwa masalah kejahatan terjadi dengan tujuan membentuk karakter manusia. Lih. Alvin Plantinga, "God, Evil, and the Metaphysic of Freedom," dalam The Problem of Evil, eds. Marilyn McCord Adams dan Robert Merrihew Adams (New York: Oxford University Press, 1990), 101-105. Lih. John Hick, Evil and the God of Love. yang tidak sewajarnya tidak harus terjadi. Dengan demikian, kasus penderitaan yang tidak sewajarnya tampaknya bertentangan dengan eksistensi Allah. ${ }^{8}$

Oleh sebab itu, teodisi-teodisi tradisional dianggap sudah tidak mampu menjawab masalah kejahatan. Masalah kejahatan menandakan tidak adanya Allah. Richard Kearney mengatakan, "The God that died in Auschwitz was the god of theodicy." Menghadapi kritik di atas, penganut teologi kontemporer seperti teologi proses mencoba menjawab permasalahan kejahatan ini bukan dengan jalan teodisi tradisional. Teodisi tradisional yang menggambarkan Allah sebagai Allah yang berdaulat, mahakuasa, dan mahabaik, tidak lagi dianggap signifikan dalam menanggapi masalah kejahatan. Sebaliknya, para teolog proses menanggapi permasalahan kejahatan dengan cara mereduksi atribut-atribut Allah, khususnya kemahakuasaan dan kedaulatan Allah. Menurut mereka, ini adalah satusatunya cara untuk menyelesaikan masalah kejahatan sehingga Allah tidak menjadi pihak yang disalahkan atas terjadinya kejahatan. William Hasker mengatakan:

Process theist uniformly claim that this gives their view a great advantage in addressing the problem of evil: if there is less that God can do than others have supposed, there is also less reason to fault God when things go badly. ${ }^{10}$

Pandangan kontemporer ini tentu saja sangat berbahaya bagi kekristenan karena pandangan ini menjadikan Allah sebagai Allah yang lemah dan tidak berdaya. Tentu saja itu tidak sesuai dengan apa yang dikatakan Alkitab mengenai Allah. Tujuan karya tulis ini adalah untuk mengkritik pandangan kon-

\footnotetext{
${ }^{8}$ Jane Mary Trau, "Fallacies in the Argument from Gratuitous Suffering," The New Scholasticism 60 (1986): 485-86.

${ }^{9}$ Richard Kearney, Anatheism: Returning to God After God (New York: Columbia University Press, 2011), 61.

${ }^{10}$ William Hasker, The Triumph of God Over Evil: Theodicy for a World of Suffering (Downers Grove: InterVarsity, 2008), 136. Lihat juga Barry L. Whitney, Evil and the Process God (New York: Edwin Mellen, 1985), 171.
} 
temporer khususnya teologi proses dalam menanggapi masalah kejahatan, dan juga membela pandangan greater good sebagai argumen yang tetap dapat dipertahankan walaupun dengan beberapa penyesuaian.

\section{Teodisi Teologi Proses dan Kritik Terhadapnya}

Teologi proses menolak teodisi tradisional mengenai alasan yang lebih tinggi (greater good) dalam peristiwa kejahatan. David Ray Griffin, seorang teolog proses mengatakan bahwa teodisi tradisional secara tidak langsung menempatkan Allah sebagai penyebab kejahatan. Lebih jauh lagi, teodisi tradisional telah mengklaim bahwa semua peristiwa kejahatan, termasuk Holocaust, adalah demi rencana kebaikan yang lebih tinggi (greater good). Menurut Griffin, inilah yang membuat banyak ateis menyerang kekristenan. ${ }^{11}$ Apakah Allah kaum tradisional yang mahabaik, mahakuasa, dan mahatahu tersebut tidak memiliki cara lain untuk mendatangkan kebaikan selain dengan cara Holocaust yang teramat kejam? Apakah Allah tidak dapat ikut campur tangan menangani kejahatankejahatan yang teramat masif? Griffin juga menyoroti bahwa jika diamati, banyak sekali peristiwa kejahatan yang sama sekali tidak mendatangkan kebaikan yang lebih tinggi. Menurut Griffin, justru kejahatan yang terjadi tampak tidak memiliki makna apa pun selain penderitaan dan kejahatan lain yang mengikutinya. Alih-alih menghasilkan perbaikan karakter, seperti yang dijanjikan teodisi pembentukan jiwa, kejahatan malah membentuk orang-orang yang semakin jahat dan menolak Tuhan. Griffin berkata,

Much suffering seems so pointless that it leads to atheism rather than to faith. The way of the world is often so cruel that it leads human beings to curse the universe and its creator rather than to love them. And so on. If the creator set up the world to produce virtuous beings, the plan seems to have back-

${ }^{11}$ David Ray Griffin, Evil Revisited: Responses and Reconsideration (New York: State University of New York Press, 1991), 14. fired on a massive scale, suggesting incompetence. $^{12}$

Griffin juga mengkritik pembelaan kehendak bebas. Ia menolak solusi yang diusung pembelaan kehendak bebas, yaitu kemenangan di kehidupan yang akan datang. Menurut Griffin, solusi kemenangan di kehidupan yang akan datang tidak memadai dalam menjawab pergumulan masalah kejahatan. Solusi itu hanyalah solusi "iman," tetapi tidak menjawab persoalan logisnya. Griffin mengatakan,

Without this belief, the traditional free-will theist admits, the kind of world we have could not be regarded as the unilateral creation of a perfectly good power. This conclusion will follow all the more if a nuclear holocaust results in agonizing illness and finally death for billions of human beings. This feature of the traditional free-will theodicy that it makes belief in life after death an essential element of the theodicy as a whole has to be regarded as a fatal weakness by those who do not believe in life after death, and as at least a serious weakness by those who think the idea doubtful. ${ }^{13}$

Sebaliknya, teologi proses memandang Allah sebagai Allah yang memiliki kuasa, tetapi kuasa yang dimiliki-Nya tidak seperti yang dijabarkan oleh para teolog tradisional. Kuasa yang dimiliki Allah adalah kuasa untuk memengaruhi dan memersuasi ciptaanNya. Ia bukan Allah yang gemar memonopoli kekuasaan dengan menentukan segala sesuatu. Allah yang memiliki kuasa absolut dan menentukan segala sesuatu, menurut teologi proses, adalah Allah para berhala. A. N. Whitehead mengatakan,

. . . the deeper idolatry, of the fashioning of God in the image of the Egyptian, Persian, and Roman imperial rulers, was retained. The Church gave unto God the attributes which belonged exclusively to Caesar. ${ }^{14}$

\footnotetext{
${ }^{12}$ Griffin, Evil Revisited, 16.
}

${ }^{13}$ Ibid., 21.

${ }^{14}$ A. N. Whitehead, Process and Reality: An Essay in Cosmology, ed. David R. Griffin dan Donald W. Sherburne (New York: Free, 1978), 342. 
Lagipula jika Allah memang memiliki kuasa yang bersifat absolut, sebagai Allah yang mahabaik harusnya Ia telah menghentikan kejahatan. Jika Allah memang mahakuasa, tetapi tidak menghentikan kejahatan, maka kemahabaikan Allah dipertanyakan. Tyron L. Inbody mengatakan,

Why God would choose to perform no miracle when we really need one to establish, maintain, or reestablish even some minimal kind of justice in a world of intense suffering. ${ }^{15}$

Oleh sebab itu, menurut mereka Allah dalam kekristenan tidak boleh dipandang sebagai Allah yang semena-mena dan memiliki kuasa yang bersifat memaksa. Allah tidak menghentikan kejahatan bukan karena Ia tidak mau menghentikannya, melainkan Ia tidak menghentikan kejahatan karena kuasa Allah bukanlah kuasa yang absolut, melainkan kuasa yang hanya mampu memengaruhi. Griffin berkata,

The reason God does not intervene in nature or human affairs to prevent some of the worst evils is not that God is evil or indifferent, or that to do so would run counter to God's policy; it is simply that God's power is of a different kind.

Kuasa Allah ini hanya mampu memberikan persuasi pada manusia supaya mengambil keputusan yang baik, namun tidak ada jaminan bahwa manusia akan mengikuti persuasi Allah. James A. Keller, seorang teolog proses mengatakan,

God, as understood in process theism, is unequivocally good, always luring every occasion toward what is best (maximum harmony and intensity in the experiences that constitute it and relevant future occasions), but God is

\footnotetext{
${ }^{15}$ Tyron L. Inbody, The Transforming God: An Interpretation of Suffering and Evil (Louisville, Kentucky: Westminster John Knox Press, 1997), 67.
}

unable to guarantee that the lure will be followed. ${ }^{16}$

Di balik semua itu, teologi proses menyatakan bahwa kasih Allah tetap menyertai manusia dalam melewati penderitaan. Sekalipun Allah tidak dapat menghentikan kejahatan dan penderitaan, Ia adalah Allah yang tetap menyertai manusia yang menderita. Bahkan Allah harus dipandang sebagai Allah yang turut menderita saat manusia menderita, dan Allah selalu setia dengan kuasa-Nya memengaruhi manusia agar memilih keputusankeputusan yang menuju kebaikan. Allah menjadi dasar bagi pengharapan manusia di tengah penderitaan. Griffin berkata,

With regard to the historical process, on the other hand, the Creative Love of God (somewhat inadequately signified by Whitehead as God's primordial nature) provides a ground for hope, if not assurance. ${ }^{17}$

Kritik terhadap pandangan teologi proses dapat dibagi menjadi dua bagian. Kritik pertama adalah jelas bahwa pandangan ini tidak Alkitabiah. Tidak ada bukti alkitabiah bahwa Allah hanya memiliki kuasa untuk memengaruhi umat-Nya. Alkitab menggambarkan Allah sebagai Allah yang berdaulat, mahakuasa, dan menentukan segala sesuatu. Lagipula, James Keller sendiri dengan jelas mengatakan bahwa dirinya tidak memercayai Alkitab sebagai sumber satu-satunya yang menyatakan sifat-sifat Allah. Keller berkata,

Sometimes, it is claimed that the important things about God that people need to know have been revealed. Many Christians claim that the Bible is or contains this revelation. But I believe that on the contrary, this claim generates a third problem of evil: it is not clear that the Bible is a divinely certified book, and it is not clear what God is communicating in it. $^{18}$

\footnotetext{
${ }^{16}$ James Keller, "Process Theism and Theodicies for Problems of Evil," The Blackwell Companion to the Problem of Evil, ed. Justin P. McBrayer dam Daniel Howard-Snyder (Oxford: Wiley Blackwell, 2013), hal 346.

${ }^{17}$ Griffin, Evil Revisited, 35.

${ }^{18}$ Keller, "Process Theism," 342.
} 
Ia bahkan mengatakan bahwa Kanonisasi Alkitab tidak dapat dipercayai seratus persen. ${ }^{19}$ Keller berpendapat bahwa kepercayaan pada Alkitab sebagai sumber yang tanpa salah inilah yang akhirnya membuat kekristenan tradisional menyimpulkan sosok Allah yang mahakuasa, mahabaik, dan mahatahu.

Let us remember that all Christians say that God loves humans and wants humans to live in love and devotion to God and infellowship with God and each other. I believe that this leads us legitimately and rightly to expect that an all-good, all-knowing, and all-powerful God would alleviate at least massive human suffering and make God's existence, character, and will for humans clearly known. ${ }^{20}$

Menurut Keller, Allah tidak hanya dapat dikenal lewat Alkitab, tetapi pewahyuan yang progresif, bahkan dalam buku-buku lain. Tampaknya ia mengemukakan hal ini untuk mendukung pandangan teologi proses, yang memang kurang memiliki bukti-bukti Alkitab. Kurangnya ayat-ayat pendukung dari pandangan ini menyatakan bahwa pandangan ini tidak berdasarkan pada Alkitab.

Kedua, pandangan teologi proses tidak memiliki akhir yang jelas. Seakan-akan Allah tidak berdaulat atas akhir dunia ini. Griffin sendiri mengakui bahwa akhir dari dunia ini tidak ditentukan oleh Allah, sekalipun kita masih tetap bisa berharap bahwa kebaikan akan menang atas kejahatan. Griffin berkata, "With regard to hope for the ultimate triumph of good over evil, process theologians have generally spoken with less confidence, but they have not been entirely mute." Memang di satu sisi, teologi proses menekankan campur tangan manusia untuk bersama-sama dengan Allah meraih kemenangan atas kejahatan, agar manusia menyadari penuh tanggung jawabnya untuk melawan dan melenyapkan kejahatan di dunia ini. Tetapi ini mengakibatkan sebuah akhir yang samar-samar. Sedangkan Alkitab sendiri menjanjikan bahwa pada akhirnya Allah akan menang atas segala kejahatan.

\footnotetext{
${ }^{19}$ Keller, "Process Theism," 343.

${ }^{20}$ Ibid., 343.
}

Teologi proses beranggapan bahwa kemenangan ataupun kekalahan atas kejahatan seutuhnya ada di tangan manusia dan ciptaan yang lain. Allah tidak bisa memaksa kita untuk menang, dan di sini Allah seutuhnya memercayakan akhir dunia pada kita semua. "Iust as the world must trust God to provide the aim for its efforts, so God must trust the world for the achievement of that aim." 21 Ini membalik pandangan Alkitab, di mana Allah bersifat independen dan tidak bergantung kepada siapa pun. Manusia yang seharusnya percaya dan bergantung kepada Allah, tetapi teologi proses membalikkan pada Allah yang harus percaya dan bergantung pada manusia untuk akhir yang baik. "He has faith in us, and it is up to us to respond in faith to him." 22

Hal ini menimbulkan keraguan terhadap solusi pandangan ini terhadap masalah kejahatan. Masalah kejahatan bisa saja tidak terkalahkan sampai selamanya. Menurut Millard J. Erickson, solusi yang diajukan oleh teologi proses termasuk dalam finitisme (membatasi kemahakuasaan Allah). Ia mengatakan bahwa finitisme bukan menyelesaikan masalah kejahatan, melainkan hanya mengakomodasi masalah-masalah yang timbul akibat masalah kejahatan. ${ }^{23}$ Bahkan menurut mereka, kematian pun bukan solusi dari masalah kejahatan, karena mereka pun tidak yakin akan adanya kehidupan setelah kematian. Griffin berpendapat bahwa keyakinan atas kehidupan setelah kematian memang banyak bermanfaat bagi manusia. Namun, apakah kehidupan setelah kematian itu diakui sebagai sebuah realitas adalah masih misteri. Lagipula hal ini juga tidak berpengaruh pada teodisi mereka, ". . . that belief in a continuing life, if included,

\footnotetext{
${ }^{21}$ Lewis Ford, "Divine Persuasion and the Triumph of Good," Problem of Evil: Selected Readings, ed. Michael Peterson (Notre Dame: Notre Dame University, 1992), 257.

${ }^{22}$ Ford, "Divine Persuasion," 258.

${ }^{23}$ Teologi proses mengakomodasi masalah-masalah yang timbul setelah terjadi masalah kejahatan, salah satunya mengenai kemahakuasaan Allah. Teologi proses memilih untuk mereduksi kemahakuasaan Allah demi menyelesaikan masalah-masalah yang muncul akibat masalah kejahatan. Lih. Millard Erickson, Teologi Kristen 1 (3 vols.; Malang: Gandum Mas, 2004), 1.666.
} 
should be an optional element, not necessary for the entire theodicy. ${ }^{24}$ Teodisi mereka sangat bergantung kepada manusia, dan Allah hanya bagaikan bayang-bayang dan bukan tokoh sentral di dalam sejarah manusia. Stephen T. Davis mengatakan bahwa Allah yang diajukan teologi proses adalah seperti seorang "mad scientist who fashions a monster he hopes will behave but whom he cannot control." 25 Pandangan ini bertentangan dengan Alkitab yang menjadikan Allah sebagai sentral sejarah manusia, dan menjanjikan kemenangan yang pasti pada akhirnya. Dengan demikian, pengharapan yang dijanjikan oleh teologi proses bukanlah pengharapan yang sejati, karena tidak mengandung jaminan apa pun di masa depan.

\section{Pembelaan terhadap Pandangan Greater Good dalam Menanggapi Masalah Kejahatan}

Jika teodisi reduksional yang dibangun oleh teologi proses gagal menanggapi persoalan kejahatan dari sisi Alkitabiah, apakah pandangan greater good masih dapat dipertahankan? Seperti yang Epicurus jabarkan, kejahatan menjadi sebuah masalah teologis karena seakan-akan Allah yang mahabaik, mahakuasa, dan berdaulat membiarkan kejahatan terjadi. Terlebih, jika Allah memang benar-benar dipandang berdaulat dan menentukan segala sesuatu, maka Ia bisa disebut sebagai penyebab kejahatan. Di sini penulis mengambil pandangan John Feinberg (modified rationalist), yang adalah modifikasi dari pandangan greater good. Feinberg melandaskan pandangannya pada determinisme lunak/ kompatibilisme, yang juga dianut oleh John Calvin, tetapi di sisi lain Feinberg juga melakukan modifikasi pada pandangan greater good klasik.

Kompatibilisme adalah pandangan yang meyakini bahwa kedaulatan Allah dan kehendak bebas adalah dua hal yang kompatibel. Pandangan ini dimulai dengan definisi kehendak bebas. Bagi kaum libertarian, kehen-

\footnotetext{
${ }^{24}$ Griffin, Evil Revisited, 40.

${ }^{25}$ Davis, "Creation Out: Critique," dalam Encountering Evil, 128.
}

dak bebas harus selalu didefinisikan sebagai kemampuan manusia untuk memilih dan dengan syarat bahwa ia dapat memilih hal yang sebaliknya. Peter van Inwagen mengatakan,

. . . almost all philosophers agree that a necessary condition for holding an agent responsible for an act is believing that the agent could have refrained from performing that act. ${ }^{26}$

Padahal kehendak bebas bisa didefinisikan dengan arti yang berbeda. Kompatibilisme mendefinisikan kehendak bebas manusia bukan mengenai kemampuan seseorang untuk memilih hal yang sebaliknya. Kebebasan manusia didefinisikan sebagai kemampuan manusia untuk memilih secara sukarela tanpa paksaan dari luar. Menurut penganut kompatibilisme, seseorang tetap dikatakan bebas walaupun ia ada dalam situasi di mana ia tidak dapat memilih yang sebaliknya. Michael Obanla mengatakan, "However for as long as that choice is made without constraint, the person choosing is said to be free in the compatibilist way." 27

Menurut seorang kompatibilis, Daniel Dennett, manusia selalu ada di dalam ruang terkunci, yaitu manusia selalu ada di dalam suatu kondisi yang telah ditetapkan. Di dalam kondisi-kondisi itu, manusia tidak dapat memilih hal yang lain selain yang telah ditetapkan. Tetapi ini tidak membuat seseorang lepas dari tanggung jawab karena orang tersebut memilih secara bebas dan sukarela, sekalipun mereka tidak bisa memilih yang sebaliknya. Dennett mendefinisikan pilihan-pilihan yang sudah ditetapkan oleh kondisi itu sebagai pilihan-pilihan rasional dan moral. Seseorang tidak akan mungkin memilih hal yang bertentangan dengan rasio dan moralnya jika

\footnotetext{
${ }^{26}$ Peter van Inwagen, "The Incompatibility of Free Will and Determinism," Philosophical Studies 25, no. 3 (March 1975): 188,

${ }^{27}$ Michael Obanla, The Problem of Evil, Modern Calvinism, and the Doctrine of Free Will: Is John Feinberg's Theodicy a Coherent Resolution to the Problem of Tragic Moral Evil (Thesis) (Virginia: Thesis Liberty Baptist Theological Seminary, 2012), 22.
} 
dihadapkan dalam kondisi tertentu. Contohnya seseorang seharusnya naik ke atas pesawat terbang, tetapi ia memilih untuk tidak masuk ke pesawat karena ia memiliki rasa takut yang sangat terhadap ketinggian. Atau membujuk seorang moralis yang kuat untuk membunuh orang lain dengan tawaran uang yang sangat besar. Moralis itu tidak mungkin mengikuti kondisi yang ditawarkan itu karena dorongan-dorongan moralnya tidak akan mengizinkan dia melakukan pembunuhan itu. Dennett mengatakan, "It is too obvious what to do; reason dictates it; I would have to be mad to do otherwise, and, since I happen not to be mad, I cannot do otherwise." ${ }^{28}$ Dorongan rasio dan moral itu membuat manusia tidak dapat memilih yang sebaliknya, tetapi tetap harus bertanggung jawab atas pilihannya karena mereka memilih secara sukarela tanpa paksaan dari luar.

Pandangan kompatibilisme ini lebih bersifat filosofis, namun para teolog Kristen juga memakai pandangan ini untuk menanggapi permasalahan kejahatan. Allah dalam kedaulatan-Nya memang telah menetapkan kondisikondisi di dalam kehidupan manusia sehingga manusia pasti memilih secara deterministik, termasuk dalam peristiwa kejahatan. Tetapi di sisi lain, manusia tetap memiliki kehendak bebas dalam kondisi-kondisi itu, dalam arti manusia melakukan pilihan tersebut secara sukarela dan tanpa paksaan berdasarkan rasio dan moral yang mereka miliki sehingga manusia harus tetap bertanggung jawab atas tindakannya tersebut. Dalam hal ini, Allah dalam kedaulatan-Nya telah mempersiapkan tujuan yang lebih tinggi (greater good), tetapi di waktu yang sama, manusia dengan kehendak bebasnya sendiri melakukan kejahatan tersebut secara sukarela sehingga manusia layak menjadi orang yang dipersalahkan karena kejahatan tersebut. Keselarasan antara kedaulatan dan kehendak bebas ini juga telah dicetuskan oleh John Calvin dalam

${ }^{28}$ Daniel C. Dennett, "I Could Not Do Otherwise, So What?" The Journal of Philosophy 81, no. 10 (October 1984): 556. doktrin providensianya. ${ }^{29}$ Calvin menyadari bahayanya seseorang menuduh Allah sebagai penyebab dari kejahatan, oleh sebab itu ia menyelaraskan pengajarannya tentang kedaulatan Allah dan kehendak bebas di dalam pengajaran mengenai penyebab sekunder. Inti dari pengajaran Calvin mengenai penyebab sekunder ini adalah Allah sering kali memakai penyebab sekunder untuk menyatakan rencana-Nya. Rencana Tuhan sudah pasti baik, tetapi dalam hal ini Ia juga memakai kejahatan untuk rencana-Nya yang baik, sebagai contoh kisah Yusuf dan Ayub. Kejahatan manusia dipakai-Nya, namun manusia yang melakukan kejahatan itu juga dianggap bertanggung jawab karena penyebab sekunder itu melakukan kejahatan atas kehendaknya sendiri.

Calvin sangat kokoh mengajarkan hal ini dan bahkan menekankan bahayanya jika tidak mengajarkan mengenai penyebab sekunder. Jika penyebab sekunder tidak diajarkan, maka "Manusia akan sama seperti batu yang tidak memiliki kehendak dan Allah akan menjadi penyebab dari kejahatan. Jika Roh Allah melakukan segala sesuatu (tanpa penyebab sekunder), maka tidak akan ada perbedaan antara Allah dan Setan, dan manusia tidak akan malu-malu berbuat jahat, sebaliknya mereka akan memuaskan hawa nafsu mereka seenaknya."30 Paul Helm mengatakan,

Calvin berusaha untuk melestarikan perbedaan itu karena itu adalah cara menjelaskan bagaimana Allah merupakan Allah

\footnotetext{
${ }^{29}$ Beberapa teolog seperti John Feinberg dan Richard Muller bahkan menganggap bahwa pandangan John Calvin adalah pandangan kompatibilisme, dilihat dari pendefinisian Calvin terhadap kehendak bebas dan tanggung jawab manusia yang sangat mirip dengan definisi kompatibilis. Lih. John Feinberg, No One Like Him (Wheaton: Crossway, 2001), 632-639. Lih. Richard Muller, "Grace Election and Contingent Choice," The Grace of God and The Bondage of the Will, ed. Thomas R. Schreiner dan Bruce A. Ware (Grand Rapids: Baker, 1995), 269.

${ }^{30}$ Calvin, Against the Libertines, dikutip dalam Susan Schreiner, Theater of His Glory: Nature and the Natural Order in the Thought of John Calvin (Grand Rapids: Baker Academic, 1991), 18.
} 
yang kudus, sekaligus merupakan Allah yang menghendaki kejahatan. ${ }^{31}$

Teolog Calvinis modern, John S. Feinberg, juga menggunakan pandangan kompatibilisme ini. Menurut Feinberg, pandangan kompatibilisme adalah pandangan yang Alkitabiah. Efesus 1:11 memberikan kesan yang sangat kuat tentang kompatibilisme, "Aku katakan 'di dalam Kristus', karena di dalam Dialah kami mendapat bagian yang dijanjikan--kami yang dari semula ditentukan untuk menerima bagian itu sesuai dengan maksud Allah, yang di dalam segala sesuatu bekerja menurut keputusan kehendak-Nya." Di ayat ini jelas dikatakan bahwa Allah bekerja dalam segala sesuatu menurut ketetapan-Nya. Tidak ada sesuatu pun terjadi di luar kedaulatan Allah. Feinberg berkata bahwa ayat ini adalah satu-satunya "scripturally acceptable way to avoid a contradiction between the clearly biblical concepts of God's sovereignty and human freedom." 32

Beberapa bukti kisah dalam Alkitab juga membuktikan bahwa ada keselarasan antara kedaulatan Allah dan kehendak bebas manusia. Dalam kisah penjualan Yusuf oleh saudara-saudaranya, tersirat adanya kompatibilisme. Ada dua hal penting yang terjadi bersamaan di dalam peristiwa ini. Pertama, Allah menetapkan hal itu terjadi untuk maksud yang baik. Kedua, di sisi lain dalam peristiwa yang sama, saudara-saudara Yusuf juga secara sukarela dan tanpa paksaan bertindak menjual Yusuf, tetapi maksud mereka adalah jahat. Ini menunjukkan bahwa dalam peristiwa penjualan Yusuf, ada unsur kedaulatan Allah yang menentukan segala sesuatu untuk maksud yang baik, namun juga ada unsur kebebasan yang sukarela dalam perbuatan saudara-saudara Yusuf untuk menjual Yusuf dengan maksud yang jahat. Selanjutnya, dalam kisah penganiayaan jemaat mula-mula

${ }^{31}$ Paul Helm, John Calvin Ideas (New York: Oxford University Press, 2004), 121.

${ }^{32}$ John Feinberg, "God Ordains All Things," dalam Predestination and Free Will: Four Views of Divine Sovereignty and Human Freedom, ed. David Basinger dan Randall Basinger (Downers Grove: InterVarsity, 1986), 32.
(Kis. 4:23-29), di satu sisi ada konspirasi jahat yang mengikutsertakan Herodes, Pilatus, para penguasa non-Yahudi, dan pemimpin Yahudi. Di sisi lain, mereka melaksanakan segala sesuatu yang telah Allah tentukan dari semula oleh kuasa dan kehendak Allah. Pola kompatibilisme yang sama juga terjadi dalam kisah penyaliban Yesus. D. A. Carson menjelaskan tentang peristiwa ini:

Apabila kita menggambarkan penyaliban Yesus Kristus hanya sebagai konspirasi dari penguasa-penguasa politik lokal pada waktu itu, dan bukan sebagai rencana Allah (mungkin Dia datang pada saat terakhir dan memutuskan untuk menggunakan kematian Yesus sebagai sebuah cara yang Dia sendiri tidak pernah perkirakan), maka akibatnya adalah bahwa salib merupakan sebuah kecelakaan sejarah. Mungkin hal itu adalah sebuah kecelakaan yang secara cerdik dimanipulasi oleh Allah untuk kepentingan-Nya sendiri, tetapi itu bukanlah bagian dari rencana Ilahi. ${ }^{33}$

Argumen determinisme lunak atau kompatibilisme ini tampaknya telah dapat menjawab bahwa Allah bukanlah penyebab kejahatan seperti yang dituduhkan oleh kaum teologi proses. Namun, pertanyaan lain muncul, yaitu apakah benar semua kejahatan selalu membawa kebaikan yang lebih tinggi (greater good)? Sebagai contoh, dalam peristiwa Holocaust. Mengapa Allah tidak menghentikan Holocaust, yang jelas adalah peristiwa kejahatan yang teramat sadis, dan seperti kata Griffin, tidak ada bukti bahwa peristiwa Holocaust mendatangkan kebaikan. Feinberg menjawab pertanyaan ini bukan dengan alasan greater good, walaupun teodisi kaum tradisional sangat yakin bahwa pasti ada alasan yang lebih baik di balik semua peristiwa kejahatan. Karena itulah pandangan Feinberg ini adalah modifikasi dari pandangan tradisional greater good. Menurut Feinberg, pandangan greater good memang memiliki kelemahan, yaitu mereka selalu yakin bahwa tiap-tiap keja-

${ }^{33}$ D. A. Carson, Doktrin yang Sulit Mengenai Kasih Allah (Surabaya: Momentum, 2010), 57. 
hatan pasti akan selalu diikuti oleh peristiwa kebaikan. Artinya, secara konsisten kebaikan selalu akan mengikuti peristiwa kejahatan. Oleh sebab itu, mereka menolak adanya kejahatan yang tidak bermakna (gratuitous evil). Tetapi pada kenyataannya, memang ada peristiwa-peristiwa kejahatan yang tampaknya tidak bermakna. Banyak peristiwa kejahatan yang tidak diikuti oleh kebaikan yang lebih tinggi. Feinberg berpendapat bahwa hal ini tidak dapat dihindari, kita harus mengakui adanya kejahatan yang tidak bermakna.

Namun ketidakbermaknaan itu tidak boleh dilihat sebagai tanpa tujuan, tetapi kejahatan tidak bermakna didefinisikan sebagai "kejahatan yang tidak langsung mendatangkan tujuan kebaikan.” Dalam hal ini, Feinberg menerima eksistensi kejahatan yang tidak bermakna tersebut. Sejalan dengan itu, Ronald Nash menerima pandangan bahwa terkadang memang ada kejahatan yang tidak bermakna, “. . . kita akan melihat bagaimana dunia di mana Allah menempatkan manusia ternyata juga terdapat sejumlah kejahatan yang tak bermakna,"34 dan "meskipun pembelaan kehendak bebas dan pembentukan jiwa berlaku sebagai dasar yang membenarkan bagi kejahatan secara umum, namun mungkin sekali bahwa beberapa, barangkali banyak, kejahatan yang spesifik yang menimpa kita tidak memiliki tujuan langsung atau tujuan yang terlihat dengan segera." 35

Tetapi di sisi lain, juga ada pembenaran bagi Allah untuk tidak menghentikan kejahatankejahatan yang tidak bermakna ini. Feinberg lebih memfokuskan masalah ini kepada diri Allah sendiri. Allah adalah Allah yang non-kontradiksi sehingga Ia tidak mungkin melawan ketetapan-Nya sendiri. Allah telah menetapkan penciptaan, serta menciptakan manusia sebagai makhluk rasional. Feinberg menjelaskan, "Allah memang mahakuasa dan

\footnotetext{
${ }^{34}$ Ronald H. Nash, Iman dan Akal Budi (Surabaya: Momentum, 2013), 342. Buku ini menyebut gratituous evil sebagai "kejahatan yang tak beralasan," namun agar selaras dengan terjemahan penulis, akan ditulis sebagai "kejahatan yang tak bermakna."
}

${ }^{35}$ Nash, Iman dan Akal Budi, 342. mampu untuk menghilangkan semua kejahatan yang ada, tetapi dengan melakukan itu, Ia akan menentang tujuan-tujuan-Nya yang telah Ia rencanakan sejak semula." 36 Jika Tuhan memang berencana menghilangkan kejahatan dari muka bumi ini, maka setidaknya ia harus mengambil salah satu dari langkah-langkah ini, yang pastinya akan menghancurkan segala sesuatu yang telah Ia rencanakan dan sedang berjalan: menghancurkan seluruh manusia yang Ia ciptakan dengan kehendak bebas, menghilangkan kemampuan manusia untuk mengingini sesuatu yang akan menuntun kepada dosa, menghilangkan kehendak bebas manusia sama sekali, membatasi gerak tubuh manusia yang menuntun pada dosa, mengambil kesadaran manusia, atau memanipulasi manusia. ${ }^{37}$

Dari penjabaran Feinberg di atas, ada dua pembelaan mengapa Allah membiarkan kejahatan terjadi. Pertama, untuk mendatangkan kebaikan yang lebih tinggi (greater good). Kedua, khusus untuk menanggapi kejahatan yang tidak bermakna, yaitu karena Allah tidak mungkin menyangkal ketetapan-Nya sendiri. Walau demikian, sesuai dengan apa yang diajarkan Alkitab, di akhir zaman Tuhan juga telah menetapkan adanya penghukuman bagi semua kejahatan untuk menyatakan keadilan-Nya. Dengan demikian, dapat dikatakan bahwa dengan menggunakan argumen ini, maka kedaulatan dan kemahakuasaan Allah tidak perlu direduksi, sebaliknya Allah juga tidak seharusnya dipersalahkan atas kejahatan yang dilakukan manusia.

${ }^{36}$ John Feinberg, "God, Freedom and Evil in Calvinist Thinking," dalam The Grace of God, The Bondage of the Will, ed. Thomas R. Schreiner dan Bruce A. Ware (Grand Rapids: Baker, 1995), 475.

${ }^{37}$ Di dalam bukunya, Many Faces of Evil, Feinberg menjabarkan delapan alasan mengapa Tuhan tidak menghilangkan kejahatan. Di artikel ini penulis meringkaskan hal tersebut. Lih. John Feinberg, Many Faces of Evil: Theological Systems and The Problem of Evil (Wheaton: Crossway, 2004), 174-180. 


\section{Kesimpulan}

Artikel ini telah menolak kritik teologi proses terhadap teodisi klasik khususnya terhadap pandangan greater good karena tidak Alkitabiah dan tidak menjanjikan sebuah akhir yang jelas. Sedangkan teodisi klasik yang mengusung konsep greater good harus dimodifikasi untuk menanggulangi kritik-kritik yang ada. Salah satu modifikasi pandangan ini adalah dengan menekankan konsep kompatibilisme, yang menerima kedaulatan Allah dan kehendak bebas sebagai sesuatu yang kompatibel. Pandangan ini mencegah kritik bahwa Allah adalah penyebab dari kejahatan. Modifikasi yang kedua datang dari John Feinberg, di mana ia sendiri mengkritik greater good karena menolak eksistensi kejahatan tidak bermakna (gratuitous evil). Feinberg menerima eksistensi kejahatan tidak bermakna ini, namun tetap menghindarkan Tuhan dari tuduhan penyebab kejahatan. Tuhan tidak mungkin menyangkal ketetapan-Nya sendiri sehingga Ia tidak mungkin menghilangkan semua kejahatan yang tidak bermakna. Tetapi perlu diingat bahwa Tuhan telah menetapkan sebuah akhir di mana keadilan akan ditegakkan bagi orang-orang benar. Dengan demikian, penderitaan kita yang sekarang ini tidak akan sebanding dengan kemuliaan yang akan datang (Rm. 8:18). 


\section{Daftar Kepustakaan}

Calvin, John. The Secret Providence, diedit oleh Paul Helm. Wheaton: Crossway, 2010.

Carson, D. A. Doktrin yang Sulit Mengenai Kasih Allah. Surabaya: Momentum, 2010.

Davis, Stephen T. "Free Will and Evil." Dalam Encountering Evil: Live Options in Theodicy, diedit oleh Stephen T. Davis. Bloomsbury: T\&T Clark, 1981.

Dennett, Daniel C. "I Could Not Do Otherwise, So What?" The Journal of Philosophy 81, no. 10 (October 1984): 553-565.

Erickson, Millard. Teologi Kristen 1. Malang: Gandum Mas, 2004.

Feinberg, John. "God, Freedom and Evil in Calvinist Thinking." Dalam The Grace of God, The Bondage of the Will, ed. Thomas R. Schreiner dan Bruce A. Ware. Grand Rapids: Baker, 1995.

Feinberg, John. "God Ordains All Things." Dalam Predestination and Free Will: Four Views of Divine Sovereignty and Human Freedom. Diedit oleh David dan Randall Basinger. Downers Grove: InterVarsity, 1986.

Feinberg, John. Many Faces of Evil: Theological Systems and The Problem of Evil. Wheaton: Crossway, 2004.

Feinberg, John S. No One Like Him: The Doctrine of God. Wheaton: Crossway, 2001.

Ford, Lewis. "Divine Persuasion and the Triumph of Good," Problem of Evil: Selected Readings. Diedit oleh Michael Peterson. Notre Dame: Notre Dame University Press, 1992.

Griffin, David Ray. Evil Revisited: Responses and Reconsideration. New York: State University of New York Press, 1991.

Hasker, William. The Triumph of God Over Evil: Theodicy for a World of Suffering. Downers Grove: InterVarsity, 2008.

Helm, Paul. John Calvin Ideas. New York: Oxford University Press, 2004.

Hick, John. Evil and the God of Love. Cleveland: Collins World, 1968.

Inbody, Tyron L. The Transforming God: An Interpretation of Suffering and Evil. Louisville: Westminster John Knox, 1997.

Inwagen, Peter van. "The Incompatibility of Free Will and Determinism." Philosophical Studies 25, no. 3 (March 1975): 185-199.

Kearney, Richard. Anatheism: Returning to God After God. New York: Columbia University Press, 2011.

Keller, James. "Process Theism and Theodicies for Problems of Evil," The Blackwell Companion to the Problem of Evil. Diedit oleh Justin P. McBrayer dan Daniel Howard-Snyder. Oxford: Wiley Blackwell, 2013.

Lactantius. "A Treatise on the Anger of God." Dalam The Ante-Nicene Fathers, vol III. Grand Rapids: Eerdmans, 1951, diedit oleh Alexander Roberts \& James Donaldson, diterjemahkan oleh William Fletcher. Dikutip dalam Clendenin, Daniel B. "God is Great, God is Good: Question About Evil." Ashland Theological Journal 24 (1992): 35-52. 
Muller, Richard. "Grace Election and Contingent Choice." Dalam The Grace of God and The Bondage of the Will, diedit oleh Thomas R. Schreiner dan Bruce A. Ware. Grand Rapids: Baker, 1995.

Nash, Ronald H. Iman dan Akal Budi. Surabaya: Momentum, 2013.

Obanla, Michael. The Problem of Evil, Modern Calvinism, and the Doctrine of Free Will: Is John Feinberg's Theodicy a Coherent Resolution to the Problem of Tragic Moral Evil (Thesis). Virginia: Liberty Baptist Theological Seminary, 2012.

Plantinga, Alvin. "God, Evil, and the Metaphysic of Freedom." Dalam The Problem of Evil, diedit oleh Marilyn McCord Adams dan Robert Merrihew Adams. New York: Oxford University Press, 1990.

Schreiner, Susan. Theater of His Glory: Nature and the Natural Order in the Thought of John Calvin. Grand Rapids: Baker Academic, 1991.

TeSelle, Eugene. Augustine. USA, Nashville: Abingdon, 2006.

Trau, Jane Mary. "Fallacies in the Argument from Gratuitous Suffering." The New Scholasticism 60 (1986): 485-9.

Whitehead, A. N. Process and Reality: An Essay in Cosmology. Diedit oleh David R. Griffin dan Donald W. Sherburne. New York: Free, 1978.

Whitney, Barry L. Evil and the Process God. New York: Edwin Mellen, 1985. 
